\title{
Guava seedlings with rootstocks or interstocks and their reaction to salinity
}

\author{
Alexandre Gomes de Souza ${ }^{1 *}$ (D) , Cláudia Sales Marinho² (D) , Mírian Peixoto Soares da Silva ${ }^{3}$ (D) , \\ Waleska Soares Gomes Carvalho ${ }^{4}$ (D) , Graziella Siqueira Campos² (ID , Bruno Abreu Pestana² (D) \\ 1.Universidade Estadual do Norte Fluminense Darcy Ribeiro - Centro de Ciências e Tecnologias Agropecuárias - \\ Laboratório de Engenharia Agrícola - Campos dos Goytacazes (RJ), Brazil. \\ 2.Universidade Estadual do Norte Fluminense Darcy Ribeiro - Centro de Ciências e Tecnologias Agropecuárias - \\ Laboratório de Fitotecnia - Campos dos Goytacazes (RJ), Brazil. \\ 3.Instituto Federal de Educação, Ciência e Tecnologia do Tocantins - Palmas (TO), Brazil. \\ 4.Universidade Estadual Paulista “Júlio de Mesquita Filho" - Faculdade de Ciências Agrárias e Veterinárias - Departamento \\ de Fitossanidade - Jaboticabal (SP), Brazil.
}

\begin{abstract}
The introduction of rootstocks for the guava has become necessary due to the advance of guava decline. Among them, Psidium spp. or their hybrids have been evaluated. In addition to disease resistance, tolerance to salinity must be evaluated in the new rootstocks. The aim of this study was to verify the effect of rootstocks and intergrafts on the mineral composition of Psidium spp. submitted to salt stress. The experiment was setup in a randomized block design, with the following treatments (scion/rootstock): P. guineense/P. cattleianum; P. guajava/P. guineense/P. cattleianum; P. guajava 'Paluma'/P. guajava; P. guajava 'Paluma'/P. guineense; P. guajava 'Cortibel 1'/P. guajava; P. guajava 'Cortibel 1'/P. guineense; P. cattleianum (purple) and P. cattleianum (yellow), with three replications and three plants per plot. The plants underwent irrigation with saline solution, and the levels of macronutrients, micronutrients and sodium in the scion leaves were evaluated. As rootstock, P. cattleianum results in greater Na uptake, with higher levels in the leaves of the scions, leading to less tolerance to salt stress.
\end{abstract}

Key words: accumulation of sodium in leaves, mineral nutrient contents in Psidium spp., interstocked seedlings.
Received:

May 05, 2019

Accepted:

Oct 102019

Section Editor:

Gabriel Constantino Blain

${ }^{*}$ Correspondence author:

alexandre.souza.agronomo@gmail.com

\section{INTRODUCTION}

In 2017, guava production in Brazil was 460,000 tons on a cultivated area of 20,000 hectares (ha), and the states of São Paulo and Pernambuco were the largest domestic producers. The crop is grown in several states in the country, which demonstrates its wide adaptability to a large range of climatic conditions and soil types. The state of Rio de Janeiro has an area of 642 ha with guava, concentrated in the districts of Cachoeiras de Macacu, São Francisco de Itabapoana, Guapimirim and São João da Barra, with 350, 70, 35 and 30 ha respectively (IBGE 2019). Guava decline has been detected in the state, a disease with a high destructive capacity, considered to be polyphagic in nature (Marques et al. 2012).

Guava decline is a complex disease, caused by a synergistic interaction between the phytonematode Meloidogyne enterolobii, and the fungus Fusarium solani (Mart.) Sacc. (Gomes et al. 2010; Gomes et al. 2011). Most nematodes in association with Fusarium predispose the formation of morphophysiological changes in the plant, hampering the absorption and/or translocation of water and nutrients, causing yellowing and reddish leaf margins, followed by wilting, necrosis and premature abscission, resulting in the death of the plants (Freitas et al. 2014). 
No source of resistance to the nematode was found in Psidium guajava; however, resistance was found in plants of the genus Psidium spp. (Carneiro et al. 2007). Costa et al. (2012) identified a genotype of P. guineense with resistance to the nematode and developed hybrids between $P$. guajava and $P$. guineense for possible use as rootstocks. Sources of resistance to $M$. enterolobii were also identified in genotypes of $P$. cattleianum by Carneiro et al. (2007), Miranda et al. (2012) and Biazatti et al. (2016). However, in guava grafted onto P. cattleianum, graft incompatibility was seen one year after planting in the field (Robaina et al. 2015).

The introduction of new rootstocks should be evaluated in relation to several factors, among the most important are their resistance to biotic features, rooting capacity and compatibility with the scion. However, the rootstocks may also influence plant response to abiotic stress, such as salinity. Water and salt stress can be induced by rainfall scarcity and inadequate irrigation management, and in the Brazilian semi-arid region this has caused serious problems to crops, also affecting guava production (Souza et al. 2007; Cavalcante et al. 2010). In a study carried out with salinity levels in plants of the 'Paluma' guava, Silva et al. (2008) found symptoms of leaf toxicity as well as reduced growth and productivity at the lowest evaluated level (electrical conductivity of $2 \mathrm{dS} \cdot \mathrm{m}^{-1}$ ).

Sá et al. (2016) reported that increased salinity restricted the emergence, growth and accumulation of biomass and the number of leaves in guava rootstocks, during the initial stages of development, with the most drastic effects at levels greater than $1.8 \mathrm{dS} \cdot \mathrm{m}^{-1}$. Silva et al. (2017) reported that an increase in electrical conductivity (EC) from $0.3 \mathrm{dS} \cdot \mathrm{m}^{-1}$ onwards negatively affected the morphophysiology of the guava rootstock 'Paluma', especially during the earliest phase, also affecting the rate of growth of the stem diameter, shoot dry matter and root to shoot ratio (Souza et al. 2017).

Plants can accumulate salts in the leaves, stems and roots. Genotypes of $P$. cattleianum that have been used in crosses aimed at the production of rootstocks for the guava (Gomes et al. 2016) should therefore be evaluated for sodium uptake.

The hypothesis of this study was to test whether P. cattleianum as rootstock enhances Na uptake to the leaves of scions inducing less tolerance to salt stress. The aim was to evaluate whether rootstocks of Psidium spp. interfere with the tolerance of the guava to salt stress.

\section{MATERIAL AND METHODS}

The experiment was conducted under greenhouse conditions, in a randomized block design, including eight treatments and three replications, with one experimental unit consisting of three plants. The treatments were scion/rootstock: (I) P. guineense/P. cattleianum, (II) P. guajava/P. guineense/P. cattleianum, (III) P. guajava 'Paluma'/P. guajava, (IV) P. guajava 'Paluma'/P.guineense, (V) P. guajava 'Cortibel 1'/P. guajava, (VI) P. guajava 'Cortibel 1'/P. guineense, (VII) P. cattleianum (purple) and (VIII) P. cattleianum (yellow).

The plants were 28 months old, and grown in Basaplant substrate in conical flasks with a capacity of $3.8 \mathrm{~L}$. Residue analysis showed the following: $\mathrm{pH} 5.95, \mathrm{~N} 6.20, \mathrm{P}_{2} \mathrm{O}_{5} 3.48, \mathrm{~K}_{2} \mathrm{O}$ 0.59, Ca 18.23, Mg 3.51 - in g. kg ${ }^{-1}$; Fe 10,811, Cu 53.50, Zn 255, Mn 447, S 0.46, B 17.02 - in $\mathrm{mg} \cdot \mathrm{kg}^{-1}$; and an EC of $1.28 \mathrm{dS} \cdot \mathrm{m}^{-1}$. The plants from each treatment were pruned and then irrigated with saline solution, which was prepared by dissolving sodium chloride $(\mathrm{NaCl})$ in the irrigation water at a concentration of $50 \mathrm{mmol} \cdot \mathrm{L}^{-1}$ at an $\mathrm{EC}$ of $5.8 \mathrm{dS} \cdot \mathrm{m}^{-1}$. On average, $200 \mathrm{~mL}$ of saline solution was applied in one irrigation every three days (Ferreira et al. 2001). To monitor the EC, three flasks from each working plot were selected before irrigation, and a plastic bag tied to the lower end of the flasks so that the irrigation water could be collected after passing over the root system. When the EC was above the maximum concentration stipulated for the experiment, the system was washed with irrigation water.

After a period of 37 days, the new emerged branches were collected. These branches were separated into leaves, and cleaned with cotton wool and deionized water. They were later dried in a forced air circulation oven at $70{ }^{\circ} \mathrm{C}$ for $48 \mathrm{~h}$ and then ground in a Wiley mill, sieved using a 20 -mesh screen and stored in hermetically sealed and 
identified bottles. The same procedure was done prior and follow induction of salinity stress, then leaves from the two collecting times were compared for nutrients composition.

To determine the levels of $\mathrm{N}$ and $\mathrm{Na}, 0.1 \mathrm{~g}$ of the dry matter was subjected to sulphuric acid digestion. Nitrogen was analyzed by the Nessler method, while $\mathrm{Na}$ was analyzed in a flame photometer. To determine the levels of $\mathrm{P}, \mathrm{K}$, $\mathrm{Ca}, \mathrm{Mg}, \mathrm{S}, \mathrm{B}, \mathrm{Cu}, \mathrm{Fe}, \mathrm{Mn}$ and $\mathrm{Zn}, 0.1 \mathrm{~g}$ of dry matter was submitted to open digestion with $\mathrm{HNO}_{3}$ and $\mathrm{H}_{2} \mathrm{O}_{2}$, using the Shimadzu ICPE-9000 plasma spectrometer. To extract the chloride, $1 \mathrm{~g}$ of dry matter was used. The $\mathrm{Cl}$ content was extracted by calcium nitrate solution in the form of the chloride ion titrated with a standard silver nitrate solution in the presence of potassium chromate as indicator. The constant application of copper fungicides prevents a precise determination of $\mathrm{Cu}$ before submission to salt stress, and this was therefore excluded from the analysis.

The data were evaluated in split-plot design with subplots corresponding to data obtained prior to and following salt stress. The variables were submitted for normality and homogeneity tests; if there were no restrictions, an analysis of variance was carried out and the mean values for each characteristic were compared by Tukey's test ( $p>0.05)$, using the SANEST statistical analysis software.

\section{RESULTS AND DISCUSSION}

The first symptoms of toxicity were noted after 18 days in the seedlings irrigated with $\mathrm{NaCl}$ solution. Initially, the apex of the distal part of the leaves presented a brownish-yellow coloration (Fig. 1a), developing into dried leaf margins, mainly in the older leaves (Fig. 1b,c), followed by leaf rolling and necrosis (Fig. 1d-f), leading to premature fall.

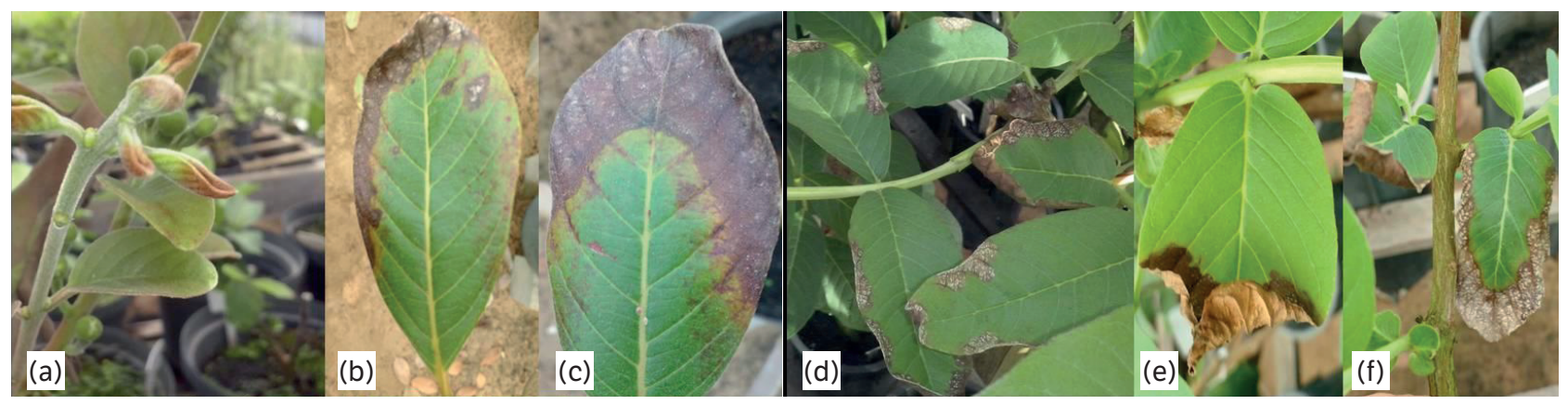

Figure 1. Initial symptoms of sodium toxicity after 18 days of induced salt stress in leaves of $P$. guineense (a), advanced symptoms of sodium toxicity in leaves of $P$. guineense grafted onto $P$. cattleianum (treatment I) after 37 days of induced salt stress (b and $\mathrm{c}$ ) and severe symptoms in leaves of $P$. guajava grafted onto $P$. cattleianum with $P$. guineese interstock that comprised treatment II (d, e, and f).

The treatments P. guineense/P. cattleianum (I), and the interstocked seedlings that comprised treatment II, both using $P$. cattleianum as rootstock, were the most sensitive to salinity and presented the greatest damage among the treatments under evaluation.

Typical symptoms of salt-stress toxicity in more sensitive species are characterized by chlorosis, followed by necrosis of the leaf tips and margins, with damage increasing from the younger to the older leaves. These symptoms were seen in each treatment irrigated with saline water (EC between 2 and $8 \mathrm{dS} \cdot \mathrm{m}^{-1}$ ) in an experiment conducted by Silva et al. (2008), and were most severe for irrigation water at $8 \mathrm{dS} \cdot \mathrm{m}^{-1}$. These symptoms were correlated with $\mathrm{Na}$ and $\mathrm{Cl}$ toxicity. The authors state that the damage seen at such low concentrations as $2 \mathrm{dS} \cdot \mathrm{m}^{-1}$, indicates that the 'Paluma' guava is sensitive to salinity. Such symptoms may simply be a consequence of changes in the water relations of the cells.

Symptoms of an excess of $\mathrm{Na}$ and $\mathrm{Cl}$ are more frequent and more serious than those of a deficiency. There may be cases of toxicity, especially in places where evaporation exceeds leaching, and leaching of the anion does not 
occur. The effects of salt stress on plant growth are dependent on exposure time and the ionic nature of the salts. In this case, quantifying tolerance to salinity among correlated species is very difficult, and after a short period of induced salinity, species with different levels of tolerance may present the same reduction in growth. Plants that are sensitive to salinity may display specific symptoms when subjected to elevated salinity levels for several days. The inability of plants to exclude $\mathrm{NaCl}$ causes damage and abscission in older leaves. In addition, the concentration of $\mathrm{Na}$ and $\mathrm{Cl}$ in the leaves increases throughout the period of salt exposure, and the leaves may be discarded by the plant due to an internal tolerance mechanism (Willadino and Camara 2010).

The use of $P$. cattleianum as rootstock in interstocked seedlings of guava plants, enabled the uptake of Na to the leaves, reducing the tolerance of the plants to salt stress. Even under conditions of low substrate salinity, the level of $2.8 \mathrm{~g} \cdot \mathrm{kg}^{-1} \mathrm{Na}$ seen in the leaves of the 'Paluma' guava interstocked with tissue from P. guineense, and with P. cattleianum as rootstock demonstrates that this rootstock led to the accumulation of $\mathrm{Na}$ in the guava leaves (Table 1).

Table 1. Mean values in $\mathrm{g} \mathrm{kg}^{-1}$ of $\mathrm{Na}$ and $\mathrm{Cl}$ in the leaf dry matter of Psidium spp. prior to $(\mathrm{P})$ and following $(\mathrm{F})$ induction to salt stress.

\begin{tabular}{|c|c|c|c|c|}
\hline \multirow{2}{*}{ Treatment } & \multicolumn{2}{|c|}{$\mathrm{Na}$} & \multicolumn{2}{|c|}{$\mathrm{Cl}$} \\
\hline & $P$ & $\mathrm{~F}$ & $P$ & $\mathrm{~F}$ \\
\hline I & $1.9 \mathrm{aA}$ & $2.6 \mathrm{bA}$ & $3.2 \mathrm{aA}$ & $2.5 \mathrm{dA}$ \\
\hline II & $2.8 \mathrm{aB}$ & $7.8 \mathrm{aA}$ & $4.1 \mathrm{aB}$ & $5.9 \mathrm{bcA}$ \\
\hline III & $0.1 \mathrm{bA}$ & $0.1 \mathrm{cA}$ & $3.8 \mathrm{aA}$ & $4.3 \mathrm{~cd} A$ \\
\hline IV & $0.1 \mathrm{bA}$ & $0.2 \mathrm{cA}$ & $5.7 \mathrm{aA}$ & $5.9 \mathrm{bcA}$ \\
\hline v & $0.1 \mathrm{bA}$ & $0.3 \mathrm{cA}$ & $4.3 \mathrm{aA}$ & $3.88 \mathrm{cdA}$ \\
\hline VI & $0.2 \mathrm{bA}$ & $0.2 \mathrm{cA}$ & $5.5 \mathrm{aA}$ & $6.00 \mathrm{bcA}$ \\
\hline VII & $2.1 \mathrm{aB}$ & $7.7 \mathrm{aA}$ & $5.4 \mathrm{aB}$ & $7.3 \mathrm{abA}$ \\
\hline VIII & $3.3 \mathrm{aB}$ & $8.3 \mathrm{aA}$ & $4.9 \mathrm{aB}$ & $9.7 \mathrm{aA}$ \\
\hline CVA (\%) & \multicolumn{2}{|c|}{15.17} & \multicolumn{2}{|c|}{15.02} \\
\hline CVB (\%) & \multicolumn{2}{|c|}{27.07} & \multicolumn{2}{|c|}{23.27} \\
\hline
\end{tabular}

Mean values followed by the same lowercase letter in a column, and uppercase letter on a row, do not differ by Tukey's test (5\%). I=P. guineense/P. cattleianum; II = P. guajava/P. guineense/P. cattleianum; III = P. guajava 'Paluma'/P. guajava; IV = P. guajava 'Paluma'/P. guineense; $V=P$. guajava 'Cortibel 1 '/P. guajava; $\mathrm{VI}=$ P. guajava 'Cortibel $1^{\prime} / P$. guineense; $\mathrm{VII}=P$. cattleianum (purple); $\mathrm{VIII}=P$. cattleianum (yellow). $\mathrm{CVA}=$ coefficient of variation in the plot and $\mathrm{CVB}=\mathrm{coefficient}$ of variation in the subplot.

Increased of $\mathrm{Na}$ content in plants of Psidium spp. grown without rootstock was also observed. However, the sodium content of the leaves from treatment I (P. guineense/P. cattleianum) showed no significant increase following the induction of salt stress. In this case, it can be deduced that the rootstock was not the only genotype responsible for the increase in the sodium content of the leaves, but that the grafting combination also played an important role (Table 1).

The leaves of $P$. cattleianum have high concentrations of sodium, and their use as rootstock or interstock has a negative effect on the tolerance of guava scions to salt stress. The P. guineense/P. cattleianum combination can be used to form interstocked plants, however, there is no study that reports the use of interstocked guava seedlings in the field, and further research should therefore be carried out. This combination accumulates sodium and chlorine in the leaves, in smaller amounts and, when used as rootstock in the guava, their content increases by approximately three times. This fact shows that the use of $P$. cattleianum as rootstock for other species of Psidium can lead to a lower tolerance of these plants to salt stress. Such plants should be evaluated in areas contaminated with the nematode, but should be avoided in saline areas.

Levels of sodium greater than $10 \mathrm{~g} \cdot \mathrm{kg}^{-1}$ in leaves of guava plants grown in nutrient solution with $0,25,50,75$, 100,125 and $150 \mathrm{mmol} \cdot \mathrm{L}^{-1} \mathrm{NaCl}$ and harvested 30 and 50 days after stress, were seen in concentrations greater 
than $50 \mathrm{mmol} \cdot \mathrm{L}^{-1} \mathrm{NaCl}$, and correlated with negative effects on the produced dry matter, as well as an imbalance between the other absorbed cations (Ferreira et al. 2001). In the present study, the interstocked seedlings (II) and the yellow P. cattleianum (VIII) reached Na levels of $7.8 \mathrm{~g} \cdot \mathrm{kg}^{-1}$ and $8.3 \mathrm{~g} \cdot \mathrm{kg}^{-1}$ respectively in the leaf dry matter harvested 37 days following the induction of salt stress.

Chlorine accumulated in the leaves following the induction of salt stress, and was larger in treatments II, VII and VIII (Table 1). It is possible that P. cattleianum has a different root system from the other genotypes of Psidium spp., and therefore absorbs $\mathrm{Cl}$ more quickly and allocates it to the plant canopy. The $\mathrm{Na}$ content was higher than the $\mathrm{Cl}$ content, up to three times more in treatments I and VII (Table 1). Studies relating the presence of an interstock to plant tolerance to salinity differ from the results obtained in the present study.

Zapata et al. (2004) found that in citrus plants, the biomass distribution of $\mathrm{Cl}$ and $\mathrm{Na}$ between the organs is variable, both when interstocked and under saline conditions. Interstocked plants had a higher biomass allocation in the leaves and roots than plants with no interstock. They also found that when the xylem vessels of an interstock have a mean lumen diameter less than that of the rootstock, graft or both, the interstock may contribute to restrict water and increase resistance to salt. The $\mathrm{Cl}$ and $\mathrm{Na}$ concentration in the leaves increased after 60 and 75 days of saline treatment respectively in interstocked plants, compared to 30 days in plants with only one graft region. However, it should be considered that the anatomy of citrus plants and Psidium spp. is different and, as such, the translocation of $\mathrm{Na}$ and $\mathrm{Cl}$ between rootstocks, interstocks and shoots must take place differently.

Sá et al. (2016) conducted an experiment with the objective of evaluating the tolerance of three guava rootstocks ('Crioula,' 'Paluma' and 'Ogawa') under salt stress during the early stages of development where the treatments consisted of five levels of irrigation water salinity $\left(0.6,1.2,1.8,2.4\right.$ and $\left.3.0 \mathrm{dS} \cdot \mathrm{m}^{-1}\right)$. The experiment showed that an increase in water salinity affected growth, biomass accumulation and number of leaves in the cultivars, having the most extreme effects at levels greater than $1.8 \mathrm{dS} \cdot \mathrm{m}^{-1}$. Guava plants diagnosed with decline had higher levels of sodium found in the leaves (Gomes et al. 2008). The authors concluded that no ranges for Na content considered phytotoxic to the guava have been reported, and as such, could not relate observed levels to the symptomatology of the disease in the aerial part of the plants.

In order to evaluate the tolerance of grapevine rootstocks under saline conditions, Viana et al. (2001) conducted a greenhouse experiment with five rootstock cultivars grown in nutrient solution at five levels of $\mathrm{NaCl}$, and demonstrated that the cultivars presented different patterns of nutrient concentration in the organs under analysis (root, stem and leaves). The most sensitive cultivars, 420-A and IAC 313, allocated a large amount of $\mathrm{Na}$ to the leaves, and displayed restrictions on the uptake of $\mathrm{K}, \mathrm{Mg}$ and $\mathrm{Ca}$. The IAC 572, IAC 766 and Ripária do Traviú cultivars, which proved to be more tolerant, were preferentially able to exclude $\mathrm{Na}$ from metabolically active regions, allocating it to the roots and stems.

For the macronutrient content, it was found that between the periods of induction, the levels of $\mathrm{N}$ and $\mathrm{K}$ did not differ significantly in the leaf dry matter; however, there was a difference between treatments. Induction to salt stress positively influenced P levels for each of the treatments under evaluation, except for treatments I and II (Table 2).

In treatments II, VII and VIII, the levels of $\mathrm{Ca}, \mathrm{Mg}$ and $\mathrm{S}$ decreased following induction to salt stress, except for S in treatment VIII (Table 2). In seedlings of the yellow passion fruit, concentrations of N, P and Ca were not affected by salinity. On the other hand, the K concentration decreased in all parts of the plant, whereas that of S only decreased in the roots (Cruz et al. 2006). Tomaz et al. (2008) evaluated genetic differences in uptake efficiency, and the transport and use of $\mathrm{K}, \mathrm{Ca}$ and $\mathrm{Mg}$ in grafted coffee seedlings. The authors found that there were variations in uptake efficiency for these nutrients in coffee plants depending on the graft/rootstock combination. As for uptake efficiency, and the translocation and utilization of $\mathrm{K}, \mathrm{Ca}$ and $\mathrm{Mg}$, as well as dry-matter production, in most cases the performance of the grafted plants was worse than that of the ungrafted plants.

Calcium is a macronutrient that is extracted and accumulated in greatest quantity in the tissue of guava plants. The levels of $\mathrm{Ca}$ in treatments II and VII were reduced, as were the levels of Mg in treatments I, II, VII and VIII following induction to salt stress (Table 2). When evaluating the levels of $S$ in the leaf, uptake is seen to be significantly lower 
in treatment II and higher in treatment VIII following induction to salt stress (Table 2). Cruz et al. (2006) found that salinity stimulated the transport of $S$ in passion fruit from the roots to the shoots and from the stem to the leaves, the leaves appearing to be the more effective drain for this nutrient. As for the micronutrient content, it was found that levels of B decreased significantly in treatments II and VII following induction to salt stress, and that the Cu content, evaluated following induction to salt stress, did not differ between treatments (Table 3).

The Fe content only differed for induction period, whereas the levels of Mn only differed between treatments. The Zn content in treatments I, II and III decreased significantly following induction to salt stress, with the lowest values being found in treatments VII and VIII (Table 3).

This study suggests that the reduction in nutrient levels in plants cultivated in saline environments may be related to the higher concentrations of $\mathrm{Na}$ and $\mathrm{Cl}$ in the soil and, consequently, in their tissue, since the presence of these elements in the substrate has been seen to reduce plant growth. This is because, among other $\mathrm{n}$.

Table 2. Mean values in $\mathrm{g} \cdot \mathrm{kg}^{-1}$ for macronutrients in the leaf dry matter of Psidium spp. prior to $(\mathrm{P})$ and following $(\mathrm{F})$ induction to salt stress.

\begin{tabular}{|c|c|c|c|c|c|c|c|c|c|c|c|c|}
\hline \multirow{2}{*}{ Treatment } & \multicolumn{2}{|c|}{$N(n s)$} & \multicolumn{2}{|c|}{$P$} & \multicolumn{2}{|c|}{$K(n s)$} & \multicolumn{2}{|c|}{$\mathrm{Ca}$} & \multicolumn{2}{|c|}{$\mathrm{Mg}$} & \multicolumn{2}{|c|}{ S } \\
\hline & $P$ & $\mathrm{~F}$ & $P$ & $\mathrm{~F}$ & $P$ & $\mathrm{~F}$ & $P$ & $\mathrm{~F}$ & $P$ & $\mathrm{~F}$ & $P$ & $\mathrm{~F}$ \\
\hline I & 13.3 & 10.3 & $1.4 \mathrm{cA}$ & $1.7 \mathrm{dA}$ & 12.7 & 14.6 & $11.1 \mathrm{bcA}$ & $14.0 \mathrm{bcA}$ & $2.3 \mathrm{cA}$ & $1.7 \mathrm{cB}$ & $2.0 \mathrm{bcA}$ & $1.6 \mathrm{dA}$ \\
\hline II & 14.6 & 12.7 & $1.8 \mathrm{bcA}$ & $2.2 \mathrm{cdA}$ & 16.2 & 15.6 & $18.1 \mathrm{aA}$ & $13.7 \mathrm{bcB}$ & $2.6 \mathrm{bcA}$ & $1.6 \mathrm{cB}$ & $2.8 \mathrm{aA}$ & $2.2 \mathrm{bcdB}$ \\
\hline III & 13.8 & 13.5 & $2.2 \mathrm{bB}$ & $3.2 \mathrm{abA}$ & 18.4 & 18.7 & $8.7 \mathrm{cB}$ & $12.1 \mathrm{cA}$ & $2.7 \mathrm{bcA}$ & $2.6 \mathrm{bA}$ & $2.7 \mathrm{abA}$ & $2.6 \mathrm{abA}$ \\
\hline IV & 16.3 & 14.7 & $3.2 \mathrm{aB}$ & $4.0 \mathrm{aA}$ & 21.2 & 19.7 & $13.8 \mathrm{abB}$ & $17.8 \mathrm{abA}$ & $2.7 \mathrm{bA}$ & $2.5 \mathrm{bA}$ & $2.7 \mathrm{aA}$ & $2.6 \mathrm{abcA}$ \\
\hline V & 14.9 & 15.2 & $2.5 \mathrm{abB}$ & $3.9 \mathrm{aA}$ & 19.5 & 21.4 & $9.1 \mathrm{cB}$ & $12.0 \mathrm{cA}$ & $2.5 \mathrm{bcA}$ & $2.5 \mathrm{bA}$ & $3.3 \mathrm{aA}$ & $3.3 \mathrm{aA}$ \\
\hline VI & 16.3 & 14.8 & $2.5 \mathrm{abB}$ & $3.7 \mathrm{aA}$ & 18.1 & 19.4 & $14.8 \mathrm{abB}$ & $21.0 \mathrm{aA}$ & $2.8 \mathrm{bA}$ & $2.7 \mathrm{bA}$ & $2.9 \mathrm{aA}$ & $3.2 \mathrm{aA}$ \\
\hline VII & 14.4 & 10.8 & $1.5 \mathrm{cB}$ & $2.2 \mathrm{cdA}$ & 25.1 & 23.5 & $16.6 \mathrm{aA}$ & $12.6 \mathrm{cB}$ & $2.5 \mathrm{bcA}$ & $1.7 \mathrm{cB}$ & $1.8 \mathrm{cA}$ & $1.7 \mathrm{dA}$ \\
\hline VIII & 9.3 & 9.7 & $1.4 \mathrm{cB}$ & $2.5 \mathrm{bcA}$ & 20.9 & 19.8 & $17.4 \mathrm{aA}$ & $15.1 \mathrm{bcA}$ & $5.0 \mathrm{aA}$ & $3.9 \mathrm{aB}$ & $1.3 \mathrm{cB}$ & $1.9 \mathrm{cdA}$ \\
\hline CVA (\%) & \multicolumn{2}{|c|}{7.91} & \multicolumn{2}{|c|}{9.23} & \multicolumn{2}{|c|}{7.41} & \multicolumn{2}{|c|}{10.38} & \multicolumn{2}{|c|}{5.24} & \multicolumn{2}{|c|}{9.21} \\
\hline CVB (\%) & \multicolumn{2}{|c|}{9.99} & \multicolumn{2}{|c|}{7.50} & \multicolumn{2}{|c|}{6.22} & \multicolumn{2}{|c|}{8.63} & \multicolumn{2}{|c|}{4.82} & \multicolumn{2}{|c|}{9.18} \\
\hline
\end{tabular}

Mean values followed by the same lowercase letter in a column, and uppercase letter on a row, do not differ by Tukey's test ( $5 \%$ ). (ns) = not significative; $\mathrm{I}=P$. guineense $/ P$. cattleianum; $\|=P$. guajava $/ P$. guineense $/ P$. cattleianum; $I I I=P$. guajava 'Paluma'/ $P$. guajava; $I \mathrm{~V}=P$. guajava ' $P$ aluma' $/ P$. guineense $; \mathrm{V}=P$. guajava 'Cortibel 1'/P. guajava; $\mathrm{VI}=$ P. guajava 'Cortibel 1'/P. guineense; $\mathrm{VII}=$ P. cattleianum (purple); $\mathrm{VIII}=P$. cattleianum (yellow). $\mathrm{CVA}=$ coefficient of variation in the plot and $\mathrm{CVB}=$ coefficient of variation in the subplot.

Table 3. Mean content in $\mathrm{mg} \cdot \mathrm{kg}^{-1}$ of micronutrients in the leaf dry matter of Psidium spp. prior to $(\mathrm{P})$ and following $(\mathrm{F})$ induction to salt stress.

\begin{tabular}{|c|c|c|c|c|c|c|c|c|c|}
\hline \multirow{2}{*}{ Treatment } & \multicolumn{2}{|c|}{ B } & \multirow{2}{*}{$\begin{array}{c}\mathrm{Cu} \\
\mathrm{F}\end{array}$} & \multicolumn{2}{|c|}{$\mathrm{Fe}$ (ns) } & \multicolumn{2}{|c|}{ Mn (ns) } & \multicolumn{2}{|c|}{$\mathrm{Zn}$} \\
\hline & $P$ & $\mathrm{~F}$ & & $P$ & $\mathrm{~F}$ & $P$ & $\mathrm{~F}$ & $P$ & D \\
\hline I & $33.8 \mathrm{abA}$ & $33.7 \mathrm{abA}$ & $9.1 \mathrm{a}$ & 129.7 & 79.4 & 32.4 & 26.3 & $19.4 \mathrm{bA}$ & $11.4 \mathrm{bB}$ \\
\hline ॥ & $40.1 \mathrm{aA}$ & $31.5 \mathrm{abB}$ & $9.4 a$ & 109.7 & 59.5 & 50.8 & 60.9 & $19.3 \mathrm{bA}$ & $11.9 \mathrm{bB}$ \\
\hline III & $29.4 \mathrm{bA}$ & $33.1 \mathrm{abA}$ & $10.6 a$ & 71.3 & 60.3 & 14.6 & 14.6 & $28.4 \mathrm{aA}$ & $21.0 \mathrm{aB}$ \\
\hline IV & $31.3 \mathrm{abA}$ & $36.2 \mathrm{aA}$ & $12.1 \mathrm{a}$ & 71.8 & 55.7 & 19.3 & 30.7 & $25.2 \mathrm{abA}$ & $21.4 \mathrm{aA}$ \\
\hline V & $25.76 \mathrm{bA}$ & $26.7 \mathrm{bA}$ & $13.0 \mathrm{a}$ & 86.6 & 54.3 & 13.9 & 13.7 & $26.7 \mathrm{aA}$ & $24.3 \mathrm{aA}$ \\
\hline VI & $31.5 \mathrm{abA}$ & $34.2 \mathrm{abA}$ & $13.9 \mathrm{a}$ & 117.8 & 63.1 & 21.5 & 29.0 & $28.2 \mathrm{aA}$ & $25.3 \mathrm{aA}$ \\
\hline VII & $38.3 \mathrm{aA}$ & $31.2 \mathrm{abB}$ & $6.2 \mathrm{a}$ & 62.6 & 45.7 & 23.7 & 18.2 & $10.6 \mathrm{cA}$ & $8.8 \mathrm{bA}$ \\
\hline VIII & $31.5 \mathrm{abB}$ & $39.2 \mathrm{aA}$ & $12.6 \mathrm{a}$ & 52.9 & 90.5 & 22.3 & 28.2 & $9.5 \mathrm{cA}$ & $10.9 \mathrm{bA}$ \\
\hline CVA (\%) & \multicolumn{2}{|c|}{7.23} & 26.89 & \multicolumn{2}{|c|}{29.84} & \multicolumn{2}{|c|}{39.63} & \multicolumn{2}{|c|}{9.97} \\
\hline CVB (\%) & \multicolumn{2}{|c|}{10.42} & 37.54 & \multicolumn{2}{|c|}{39.84} & \multicolumn{2}{|c|}{21.03} & \multicolumn{2}{|c|}{13.12} \\
\hline
\end{tabular}

Mean values followed by the same lowercase letter in a column, and uppercase letter on a row, do not differ by Tukey's test $(5 \%)$. (ns) = not significative; $I=P$. guineense/P. cattleianum; II = P. guajava/P. guineense/P. cattleianum; III = P. guajava 'Paluma'/P. guajava; IV = P. guajava 'Paluma'/P. guineense; $\mathrm{V}=P$. guajava 'Cortibel 1 '/P. guajava; $\mathrm{VI}=P$. guajava 'Cortibel 1 '/P. guineense; $\mathrm{VII}=P$. cattleianum (purple); $\mathrm{VIII}=P$. cattleianum (yellow). $C \mathrm{VA}=$ coefficient of variation in the plot and $C V B=$ coefficient of variation in the subplot. 


\section{CONCLUSION}

P. cattleianum as rootstocks for Psidium spp. increases the concentration of $\mathrm{Na}$ in the leaves of the scions, inducing less tolerance to salt stress. The presence of an interstock does not prevent an increase in the sodium concentration in the scion leaves.

\section{ACKNOWLEDGMENTS}

The authors thank the Universidade Estadual do Norte Fluminense Darcy Ribeiro (UENF) for the infrastructure to conduct the experiment.

\section{FUNDING}

Fundação Carlos Chagas Filho de Amparo à Pesquisa do Estado do Rio de Janeiro

[http://doi.org/10.13039/501100004586]

Conselho Nacional de Desenvolvimento Científico e Tecnológico

[http://doi.org/10.13039/501100003593]

\section{AUTHORS' CONTRIBUTION}

Conceptualization, Souza A. G. and Marinho C. S.; Methodology, Souza A. G., Silva M. P. S., Carvalho W. S. G., Campos, G. S. and Pestana B. A.; Investigation, Souza A. G., Silva M. P. S. and Marinho C. S.; Writing - Original Draft, Souza A. G., Marinho C. S. and Silva M. P. S.; Writing - Review and Editing, Souza A. G.; Funding Acquisition, Silva M. P. S. and Marinho C. S.; Resources, Silva M. P. S. and Marinho C. S.; Supervision, Marinho C. S.

\section{REFERENCES}

[IBGE] Instituto Brasileiro de Estatística e Geografia (2019). Área destinada à colheita, área colhida, quantidade produzida e valor da produção da lavoura permanente. [Accessed on May 8, 2019]. Available at: http://sidra.ibge.gov.br/tabela/5457

Biazatti, M. A., Souza, R. M., Marinho, C. S., Guilherme, D. O., Campos, G. S., Gomes, V. M. and Bremenkamp, C. A. (2016). Cattley guava genotypes resistance to Meloidogyne enterolobii. Ciência Rural, 46, 418-420. https://doi.org/10.1590/0103-8478cr20140488

Carneiro, R. M. D. G., Cirotto, P. A., Quintanilha, A. P., Silva, D. B. and Carneiro, R. G. (2007). Resistance to Meloidogyne mayaguensis in Psidium spp. Accessions and their grafting compatibility with P. guajava cv. Paluma. Fitopatologia Brasileira, 32, 281-284. https://doi.org/10.1590/S0100-41582007000400001

Cavalcante, L. F., Vieira, M. S., Santos, A. F., Oliveira, W. M. and Nascimento, J. A. M. (2010). Água salina e esterco bovino líquido na formação de mudas de goiabeira cultivar Paluma. Revista Brasileira de Fruticultura, 32, 251-261. https://doi.org/10.1590/ S0100-29452010005000031

Costa, S. R., Santos, C. A. F. and Castro, J. M. C. (2012). Assessing Psidium guajava $\times$ P. guineense Hybrids Tolerance to Meloidogyne enterolobii. Acta Horticulturae, 959, 59-66. https://doi.org/10.17660/ActaHortic.2012.959.6 
Cruz, J. L., Pelacani, C. R., Coelho, E. F., Caldas, R. C., Almeida, A. Q. D. and Queiroz, J. R. D. (2006). Influência da salinidade sobre o crescimento, absorção e distribuição de sódio, cloro e macronutrientes em plântulas de maracujazeiro-amarelo. Bragantia, 65, 275-284. https://doi.org/10.1590/S0006-87052006000200009

Ferreira, R. G., Távora, F. J. A. F. and Hernandez, F. F. F. (2001). Distribuição da matéria seca e composição química das raízes, caule e folhas de goiabeira submetida a estresse salino. Pesquisa Agropecuária Brasileira, 36, 79-88. https://doi.org/10.1590/ S0100-204X2001000100010

Freitas, V. M., Correa, V. R., Motta, F. C., Sousa, M. G., Gomes, A. C. M. M., Carneiro, M. D. G., Silva, D. B., Mattos, J. K., Nicole, M. and Carneiro, R. M. D. G. (2014). Resistant accessions of wild Psidium spp. to Meloidogyne enterolobii and histological characterization of resistance. Plant Pathology, 63, 738-746. https://doi.org/10.1111/ppa.12149

Gomes, V. M., Ribeiro, R. M., Viana, A. P., Souza, R. M., Santos, E. A., Rodrigues, D. L. and Almeida, O. F. (2016). Inheritance of resistance to Meloidogyne enterolobii and individual selection in segregating populations of Psidium spp. European Journal of Plant Pathology, 148, 699-708. https://doi.org/10.1007/s10658-016-1128-y

Gomes V. M., Souza, R. M., Corrêa, F. M. and Dolinski, C. (2010). Management of Meloidogyne mayaguensis in commercial guava orchards with chemical fertilization and organic amendments. Nematologia Brasileira, 34, 23-30.

Gomes, V. M., Souza, R. M., Mussi-Dias, V., Silveira, S. F. and Dolinski, C. (2011). Guava decline: a complex disease involving Meloidogyne mayaguensis and Fusarium solani. Journal of Phytopathology, 159, 45-50. https://doi.org/10.1111/j.1439-0434.2010.01711.x

Gomes, V. M., Souza, R. M., Silva, M. M. and Dolinski, C. (2008). Caracterização do estado nutricional de goiabeiras em declínio parasitadas por Meloidogyne mayaguensis. Nematologia Brasileira, 32, 154-160.

Marques, M. L. S., Pimentel, J. P., Tavares, O. C. H., Menezes Veiga, C. F. and Berbara, R. L. L. (2012). Hospedabilidade de diferentes espécies de plantas a Meloidogyne enterolobii no estado do Rio de Janeiro. Nematropica, 42, $304-313$.

Miranda, G. B., Souza, R. M., Gomes, V. M., Ferreira, T. F. F. and Almeida, A. M. (2012). Avaliação de acessos de Psidium spp. quanto à resistência a Meloidogyne enterolobii. Bragantia, 71, 52-58. https://doi.org/10.1590/S0006-87052012005000001

Robaina, R. R., Campos, G. S., Marinho, C. S., Souza, R. M. and Bremenkamp, C. A. (2015). Grafting guava on cattley guava resistant to Meloidogyne enterolobii. Ciência Rural, 45, 1579-1584. https://doi.org/10.1590/0103-8478cr20131412

Sá, F. V. S., Nobre, R. G., Silva, L. A., Moreira, R. C., Paiva, E. P. and Oliveira, F. A. (2016). Tolerance of guava rootstocks under salt stress. Revista Brasileira de Engenharia Agrícola e Ambiental, 20, 1072-1077. https://doi.org/10.1590/1807-1929/agriambi. v20n12p1072-1077

Silva, A. B. F., Fernandes, P. D., Gheyi, H. R. and Blanco, F. F. (2008). Growth and yield of guava irrigated with saline water and addition of farmyard manure. Revista Brasileira de Ciências Agrárias, 3, 354-359.

Silva, E. M., Nobre, R. G., Souza, L. P., Araújo, R. H. C. R., Pinheiro, F. W. A. and Almeida, L. L. S. (2017). Morphophysiology of guava rootstock irrigated with salted water under nitrogen doses. Comunicata Scientiae, 8, 32-42. https://doi.org/10.14295/ CS.v8i1.1547

Souza, E. R., Montenegro, A. A. A., Santos, F. X. and Costa Neto, M. L. (2007). Dinâmica da condutividade elétrica em Neossolo Flúvico no semi-árido. Revista de Biologia e Ciências da Terra, 7, 124-131.

Souza, L. P., Nobre, R. G., Silva, E. M., Gheyi, H. R. and Soares, L. A. A. (2017). Produção de porta-enxerto de goiabeira cultivado com águas de diferentes salinidades e doses de nitrogênio. Revista Ciência Agronômica, 48, 596-604. https://doi. org/10.5935/1806-6690.20170069

Taiz, L., Zeiger, E., Moller, I. M. and Murphy, A. (2017). Fisiologia e desenvolvimento vegetal. 6.ed. Porto Alegre: Artmed. 
Tomaz, M. A., Martinez, H. E. P., Cruz, C. D., Ferrari, R. B., Zambolim, L. and Sakiyama, N. S. (2008). Diferenças genéticas na eficiência de absorção, na translocação e na utilização de K, Ca e Mg em mudas enxertadas de cafeeiro. Ciência Rural, 38, 1540-1546. https://doi.org/10.1590/S0103-84782008000600008

Viana, A. P., Bruckner, C. H., Martinez, H. E. P., Martinez y Huaman, C. A. and Mosquim, P. R. (2001). Teores de Na, K, Mg e Ca em porta-enxertos de videira em solução salina. Scientia Agricola, 58, 187-191. https://doi.org/10.1590/S0103-90162001000100028

Willadino, L. and Camara, T. R. (2010). Tolerância das plantas à salinidade: aspectos fisiológicos e bioquímicos. Enciclopédia Biosfera, 6, 1-23.

Zapata, J. C. M., Cerdá, A. and Nieves, M. (2004). Interstock-induced mechanism of increased growth and salt resistance of orange (Citrus sinensis) trees. Tree Physiology, 24, 1109-1117. https://doi.org/10.1093/treephys/24.10.1109 